\title{
COVID-19 and Book Publishing: Impacts and Insights for 2021
}

\author{
Cliff Guren ${ }^{1} \cdot$ Thad Mcllroy $^{2} \cdot$ Steven Sieck $^{3}$
}

Accepted: 19 January 2021 / Published online: 19 February 2021

(C) The Author(s), under exclusive licence to Springer Science+Business Media, LLC part of Springer Nature 2021

\begin{abstract}
The impact of COVID-19 on different industries, markets, and segments of society has varied widely. Book publishers, on the whole, fared well in 2020, escaping many of the COVID-inflicted disruptions faced by several other sectors. In COVID19 and Book Publishing: Impacts and Insights for 2021, three publishing industry consultants explore COVID-19's effects on the U.S. book publishing market, including trade, K-12 and higher education, along with specific analyses of bookstores and libraries.
\end{abstract}

Keywords COVID-19 $\cdot$ Book publishing $\cdot$ Higher education publishing $\cdot$ K-12 publishing $\cdot$ Trade publishing $\cdot$ Bookstores $\cdot$ Entertainment industry $\cdot$ Streaming media $\cdot$ Libraries $\cdot$ eBooks $\cdot$ Audiobooks

\section{Introduction}

COVID-19 and Book Publishing: Impacts and Insights for 2021 examines the impact of COVID-19 on sectors aligned with or adjacent to book publishing, in order to understand the broader impact that COVID may be having on the publishing

Thad McIlroy

thad@thefutureofpublishing.com

http://thefutureofpublishing.com

Cliff Guren

cguren@syntopical.com

http://syntopical.com

Steven Sieck

steve@sksadvisors.com

http://sksadvisors.com

1 Syntopical, Seattle, WA, USA

2 The Future of Publishing, San Francisco, CA, USA

3 SKS Advisors, New York, NY, USA 
industry. It seeks to provide context via macro views of the economy overall and consumer spending more specifically.

The methodology is based squarely on secondary research. We have combed through publicly-available literature produced during the pandemic, including articles, studies, blogs and other resources. To this review of recent coverage, we have added our own perspectives and takeaways regarding the implications for the book publishing industry, including trade, educational, and, to a lesser extent, academic.

\section{The Economy}

COVID is unquestionably in control of the U.S. and world economy. Until the spread of the virus is halted or significantly diminished for a sustained period it will be impossible for anyone to offer a reliable economic forecast, short-term or longerterm. The question we address here is, within the available data and forecasts, how will changes within the broader economy impact both book publishing and retailing in 2021, and beyond.

\section{Key U.S. Data}

Gross Domestic Product in the United States contracted roughly $2.4 \%$ in 2020 . The Federal Reserve projects $4.2 \%$ growth in 2021 [1]. The unemployment rate, which stood at $3.5 \%$ in January, 2020, peaked at $14.7 \%$ in April, then dropped to $6.7 \%$ by the end of December [2]. New lockdowns in early 2021 are increasing the rate, at least in the short term. The Conference Board Consumer Confidence Index fell to 88.6 in December, 2020, down from November's $92.9(1985=100)$ [3]. Despite the bad economic news, U.S. stock markets hit historic highs in mid-December, with the Dow Jones breaking through 30,300, the Nasdaq Composite above 12,750, and the S\&P 500 reaching 3722 [4].

\section{Consumer Spending}

Data on trends in personal income and consumer spending turned negative in November, 2020: personal income dropped by $1.1 \%$ and consumer spending by $0.4 \%[5]$.

Book purchasing and book reading skew heavily toward higher incomes. In one Bureau of Labor Statistics survey, the top $10 \%$ of earners spent nearly $81 / 2$ times more on reading than the bottom $10 \%$. And so while the pandemic is hitting lower earners financially more heavily than the more prosperous, this is at worst a minor negative indicator for publishing's sales and bottom line [6].

Consumer behaviors that were spotted early in the pandemic were, if anything, becoming more entrenched at the end of 2020. 


\section{The U.S. Economy in 2021}

In December, 2020, the Wall Street Journal struck an optimistic note on the U.S. economy. "The story of 2021, however, will be of a great comeback...When it is safe for business to resume as usual, the economy could take off." The factors identified are:

- New business applications have nearly doubled.

- Pandemic savings deposits of $\$ 2$ trillion are waiting to be spent.

- People will continue to save time and money formerly spent on commuting [7].

A Bloomberg survey of Wall Street banks found growth forecasts for 2021 ranging from $5 \%$ to $6.4 \%$ [8].

\section{State Budgets to Take a Hit}

Total U.S. state budget shortfalls through 2022 could be "greater than the K-12 education budget for every state combined in 2019." Deficits have already prompted tax hikes and cuts to education, corrections services and parks. State workers have been laid off. Libraries fear cuts.

While many states were in a better position pre-COVID than they were heading into the 2008 crisis, Moody's Analytics projects that 46 states will be coming up short "even after rainy day funds are used [9]".

\section{Retail}

Physical retail and online retail have taken dramatically different paths during the pandemic. Well-established chains like Brooks Brothers, GNC, J. Crew, and Neiman Marcus have all made Chapter 11 filings, while Amazon, eBay, Walmart, and Target reported record sales.

While book publishing, generally, has performed strongly thus far during the pandemic, bookstores have not.

\section{The Data}

Overall retail sales changed only slightly in 2020, but there were huge swings month-to-month. April sales were down 14.7\% from March, but were followed by an $18.3 \%$ jump in May [10]. November retail sales dropped $1.1 \%$ from October, but were up $4.1 \%$ from November 2019 [11]. In 2020, forty U.S. retailers filed for Chapter 11 since the pandemic started forcing shutdowns in March, 2020, and more than 8600 stores closed [12]. 


\section{The Continuing Shift to Online Spending}

E-commerce represented $11.3 \%$ of retail sales at the end of 2019. In Q1 2020 it climbed modestly to $11.8 \%$. By the end of Q3 it stood at $13.5 \%$, an increase of $36.7 \%$ from the third quarter of 2019 [13]. As Accenture noted, in a theme repeated elsewhere in our report, online retail saw " 10 years of growth in a matter of months [14]".

One big question is whether the increased shift toward e-commerce will hold once the outbreak subsides. Moody's retail analyst team is projecting online sales to "shoot above" $25 \%$ of all retail sales over the next five years [15].

\section{Higher Education}

Higher education institutions are facing major challenges as a result of the pandemic, with all but the most elite and well-endowed confronting budget cuts, falling enrollments, and increased focus on some basic questions about the value and purpose of post-secondary education. Pre-COVID-19 there were numerous existing stresses on higher education institutions, including rising costs for students; greater faculty competition for increasingly scarce research funding; growing concerns about student debt; and alarm over post-graduation unemployment and underemployment [16].

COVID-19 has brought a new and even more immediately daunting set of stresses to these institutions, including the expectation of large budget cuts; growing reluctance among students to pay full tuition fees for online education; decreasing enrollments of international students who pay full fees; and questions of how and whether to reopen [17].

A letter to Congress from the American Council of Education and other organizations representing two- and four-year colleges in the U.S. estimated that the financial impact on American colleges and universities will easily top \$120 billion [18].

\section{Impact on Higher Education Publishers}

The likely long-term contraction of higher education institutions overall, as well as the immediate drop in demand for printed textbooks, have added to longstanding existing challenges for publishers in the sector.

As a prominent example, in August Moody Investor Service had dropped the credit ratings of McGraw Hill and Cengage Learning Inc. from B3 to Caa2, nearly the lowest rating possible without actually delaying debt payments. It had previously cut Pearson Plc to the brink of junk bond rating [19].

However, higher education publishers' longstanding investments in digital learning solutions are now paying off. 
- Revenue in Pearson's global online learning segment grew 32\% in the third quarter of 2020, and the company recorded strong growth in digital and subscription services in its U.S. courseware unit [20].

- McGraw Hill reported double-digit increases in overall digital billings in its fiscal Q2 2021 quarter [21].

- Cengage saw $40 \%$ year-over-year growth in online skills revenue, and digital sales growth that more than offset print declines in its first half of fiscal 2021 [22].

\section{K-12 Schools}

As every parent of young children can attest, the K-12 education market has been hit hard by the pandemic, creating major challenges for students, parents, and educators as teaching has moved online. School districts are facing harsh budget challenges amid rising costs. Yet there is also optimism that the forced acceleration of distance learning approaches will result in much-needed reforms and innovations.

\section{The Scope of Impact}

As a global phenomenon, COVID-19 has impacted education worldwide. At its initial peak in mid-April, the virus caused nationwide school closures in 190 countries, impacting $90 \%$ of total enrolled learners, or almost 1.6 billion people globally [23].

As K-12 school districts braced for the costs of designing and implementing new remote learning programs, and new costs for childcare, transportation, and significant costs associated with providing students with computers and other essential equipment, such as $\mathrm{Wi}-\mathrm{Fi}$ access points.

\section{Acceleration of Distance Learning Trends}

Observers have commented that, as in other areas of life, the pandemic has moved digital learning in public education ahead by as much as a decade, and settled in many ways the question of whether digital tools have a place in schools. To some, at least, it is "proving that you can learn anywhere and anytime."[24]

Some school administrators predict that, now that school communities are more comfortable with video conferencing and asynchronous learning approaches, there will be demand for the choice of in-person and online learning post-pandemic [25].

\section{Impact on K-12 Publishers}

In their immediate response to COVID-19, scores of publishers and education technology providers offered their services for free. That was helpful to students, parents, and educators moving their teaching online, but it was also an opportunity for providers to gain a place in the rapidly evolving market for educational content and services [23]. 
However, a survey of education industry companies by EdWeek found that most K-12 companies were planning to switch districts from free use of products to paid models - at the end of the summer, or the end of the coming academic year, or beyond. Sixty-five percent of companies that had offered free products during COVID-19 tried to convert districts to paid, but with mixed success [26].

While the biggest publishers serving the K-12 market saw disruption in their traditional textbook businesses, they also benefited from the shift to digital offerings. Although overall sales declined by $14 \%$ reflecting the impact of COVID-19, Pearson recorded growth of 14\% YOY in Global Online Learning in the first 9 months of 2020 , driven by $41 \%$ enrollment growth in Virtual Schools (accredited private virtual K-12 schools) for the academic year 2020/2021 [27].

McGraw Hill saw its "total market opportunity" in K-12 decline by $21 \%$ in fiscal Q2 year-to-date, with sales shifting from Q1 to Q2 after school district closures and delayed shipments [28]. But Houghton Mifflin Harcourt reported K-12 SaaS billing growth of $147 \%$ over the previous 12 months, and digital platform usage growth of $388 \%$ over the same period, while net sales overall declined $32 \%$ in the third quarter and $28 \%$ year-to-date. At the same time, it announced its intent to explore the sale of its consumer publishing business in order to focus on creating a pure-play learning technology company [29].

\section{Entertainment Industries}

The pandemic has also affected the entertainment industry, although the impact on the video gaming, streaming video, streaming music, and films sectors has varied widely. Gaming is seeing unprecedented growth while the film industry is experiencing unprecedented challenges. Homebound consumers have shifted to online discovery and consumption of content. The companies that have been most successful during this time have been those with the capability to stream content directly to consumers, in their homes and/or on their mobile devices. They are for the most part companies with subscription-based business models. With multi-generational families to entertain and stretched budgets, consumers are looking for low-cost access to libraries of content that have something for everyone.

\section{Gaming}

Gaming was one of 2020's great success stories. The World Economic Forum estimates global gaming revenue will hit $\$ 165$ billion this year, with 2.7 billion gamers worldwide. Gaming is already the world's favorite form of entertainment, with annual revenues that surpass TV, movies, and music [30]. COVID has only strengthened gaming's already dominant position, in large part due to the fact that gaming began shifting to online and mobile platforms in the early 2000s, meaning that gaming platform companies and gamers were already connected when the pandemic hit [31]. The ensuing lockdowns put gamers right where gaming platform companies wanted them: in front of their PCs, mobile devices, and televisions. 


\section{Music}

Streaming is fueling recorded music industry revenues, with growing subscriber revenues and paid subscription numbers. According to the Recording Industry Association of America (RIAA), streaming music revenues grew 12\%, to $\$ 4.8$ billion in the first half of 2020 . Paid subscription revenues grew $14 \%$ to $\$ 3.8$ billion [32]. Spotify, with 32\% of the global streaming market, and Apple Music, with $18 \%$, are still the two top players in the space [33].

\section{Streaming Video}

Streaming video services also grew dramatically during 2020: Antenna Analytics estimated that annual video streaming revenues for 2020 would grow by "a staggering 37 percent year-on-year, with most of that growth coming from Disney +." Disney + is now the third largest streaming service in the U.S., just behind Hulu. Netflix is still number one. (Note that Antenna does not track Prime Video.) [34] The large players like Netflix, Disney, HBO, Hulu, Amazon, and Apple are investing heavily in content to win and retain customers. This is great for consumers who are getting more and more quality entertainment for their monthly subscription fees, and bad for the other forms of entertainment that have to compete for the time and attention of those same consumers. The fierce competition for subscribers is a growing problem for the streaming services, especially the newer entrants: the Q3 2020 churn rate (the percentage of subscribers who discontinue their subscriptions within a given period of time) for newcomers HBO Max, Apple TV+, and Peacock is about 20\% vs. Netflix's estimated 3\% churn rate [35].

\section{Film}

The film industry has been upended by the COVID-19 pandemic: film production was halted, theaters were shuttered, the release dates for the year's blockbusters were pushed back, then pushed back again as the virus surged across the country. The studios have been experimenting with alternate distribution models, including releasing first run for rental ahead of or simultaneously with theater release. But consumers haven't been enthusiastic about paying \$20 to \$30 on home rental of first-run movies [36]. There's simply too much quality content available on the subscription services they already pay for, and subscribing to a new service for a month costs significantly less than paying for a single first run release.

\section{Libraries}

$\mathrm{BC}$-Before COVID — a major issue at the intersection of publishing and libraries involved the conflict over the terms under which publishers would offer ebooks. It was a given that they would charge as much as three or four times the full retail 
price. It was also a given that the price wasn't in fact for a sale, but rather a oneor two-year lease payment (or sometimes a meter charge, for example, 26 loans maximum per license). But would publishers allow their hot new titles into the library channel at all, or only after sales of those titles had cooled?

And then, in February, ebook demand exploded, both at retail and through libraries. Publishers like Macmillan declared a ceasefire. As reported in Publishers Weekly, "in mid-March, when the reality of the pandemic became apparent... dozens of publishers began slashing library ebook and digital audio prices and easing restrictions... Macmillan abruptly abandoned its embargo on new release library ebooks [37]".

Library ebook aggregator Overdrive reported that, by the summer of 2020, weekly library ebook lending had increased by nearly 50\% [38]. Also, according to Overdrive, in K-12 schools borrowing was up to nearly three times the levels of 2019 [39]. At the same time that ebook borrowing was exploding, libraries were facing potential budget cuts because of the fallout of COVID-19's impact on state funds. On December 8, the American Library Association (ALA) issued a news release "urging library advocates to contact their U.S. representatives and senators with an ask to provide funding for libraries in a COVID relief package as House and Senate members work to pass an emergency assistance plan before adjourning for the year." (The bill proposed in late December did not include special funding for libraries.) [40]

According to an Ithaka $\mathrm{S}+\mathrm{R}$ study of academic libraries released in December, "most libraries have experienced budget cuts in the current academic year and there is great uncertainty about longer-term financial recovery." At the same time, the "pandemic reinforced and accelerated trends in library investments toward digital resources and services [41]".

\section{Bookstores}

Book retail is really a set of businesses. First, it's both physical and digital. More than half of all book retail takes place online (with Amazon accounting for at least half of those sales). Physical retail, on its own, has several components, broadly speaking: chain bookstores, independent bookstores, big box retailers like Costco, and "newsstands" at drug and grocery stores, airport stores, etc.

Then there is digital, capturing more than $10 \%$ of most book publisher sales, and the vast majority of self-publishing sales. Amazon controls at least three-quarters of that market [42]. Academic and educational publishing have different retail profiles.

Despite much positive news around publisher net sales, the U.S. Census data show that bookstore sales declined $28.8 \%$ in October 2020 vs. 2019 and 31\% YTD [43, 44].

Amazon sales have exploded during the COVID crisis. In the three months ended September 30, Amazon's net sales increased by 37\% over 2019 (Amazon never breaks out book sales revenue separately.) [45] Early in the pandemic Amazon prioritized what it deemed to be essential items and let book order fulfillment lag. This had a negative short-term impact on book publishers, but seems to be no longer a 
significant business issue impacting overall book sales. It did, however, further highlight Amazon's central position in the bookselling ecosystem.

\section{Barnes and Noble's Tough Year}

In June, 2019, when the hedge fund Elliott Management acquired Barnes \& Noble's then 627 stores, for a deal valued at over $\$ 680$ million, there was not even an inkling that the money-losing chain would face perhaps the toughest time in its history starting just eight months later [46].

Through the summer of 2020, Barnes \& Noble, like most independent booksellers, balanced opening restrictions against offering online order pickup and greatly expanded online sales. It temporarily shuttered more than 400 of its 600 -plus stores in the United States in April and May. By late fall, cafe and magazine newsstand sales were still down significantly, but book sales were actually running ahead of a year ago, aided by a doubling in online sales [47].

\section{Publishing}

COVID-19's impact on publishing sales and the supply chain has been less than many feared it would be. Whatever doom and gloom surround the publishing industry in the midst of the COVID crisis, sales cannot be singled out for scorn. Trade sales in 2020 were almost uniformly ahead of 2019, and in several categories unit sales were up over $20 \%$ through mid-December.

With sales strong, there have been no major bankruptcies. Supply chain issues, which early in the pandemic appeared dire, have for the most part resolved themselves. It's not perfect, but things are working_-books are being printed, distributed and purchased.

\section{The Data}

Data from the Association of American Publishers (AAP) and NPD shows solid gains across most publishing sectors in 2020.

The AAP tracks publishing sector sales. Even higher education (which fell by $10.9 \%$ in 2019) is up 2.3\% through the end of October (see separate Education section). In the largest sector, trade publishing (including children's and young adult), sales are up by $7.5 \%$ to October 31, after a mere $0.4 \%$ increase in 2019 (and $1.5 \%$ in 2018) [48]. It seems inconceivable that the industry would have enjoyed these gains without the COVID catastrophe (Fig. 1).

NPD data on print unit sales (as reported by Publishers Weekly), based on retailer reports not publisher data, is even more impressive. Unit trade sales were up overall by $8.2 \%$ through January 2, 2021. Juvenile and young adult fiction and nonfiction all enjoyed double-digit increases; adult books far less, in the 5-6\% range [49] (Fig. 2).

Unit sales by format show the greatest gains in hardcover and trade paperback formats. Mass market was down 5.5\% for the year [49] (Fig. 3). 


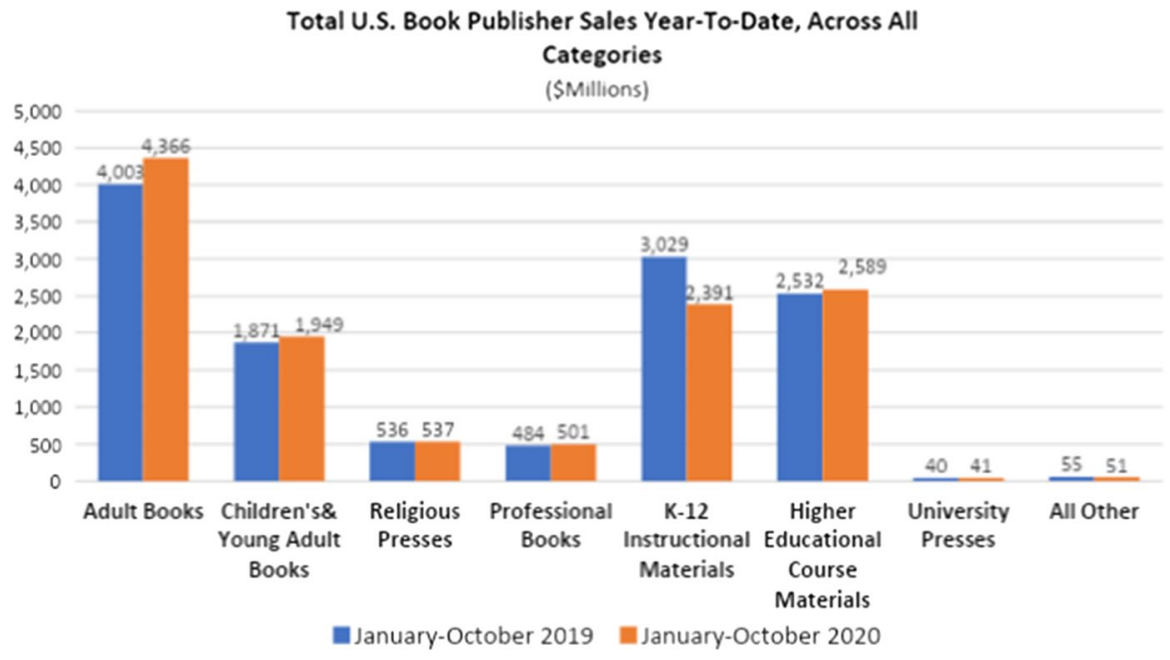

Fig. 1 Source: Association of American Publishers, December 2020

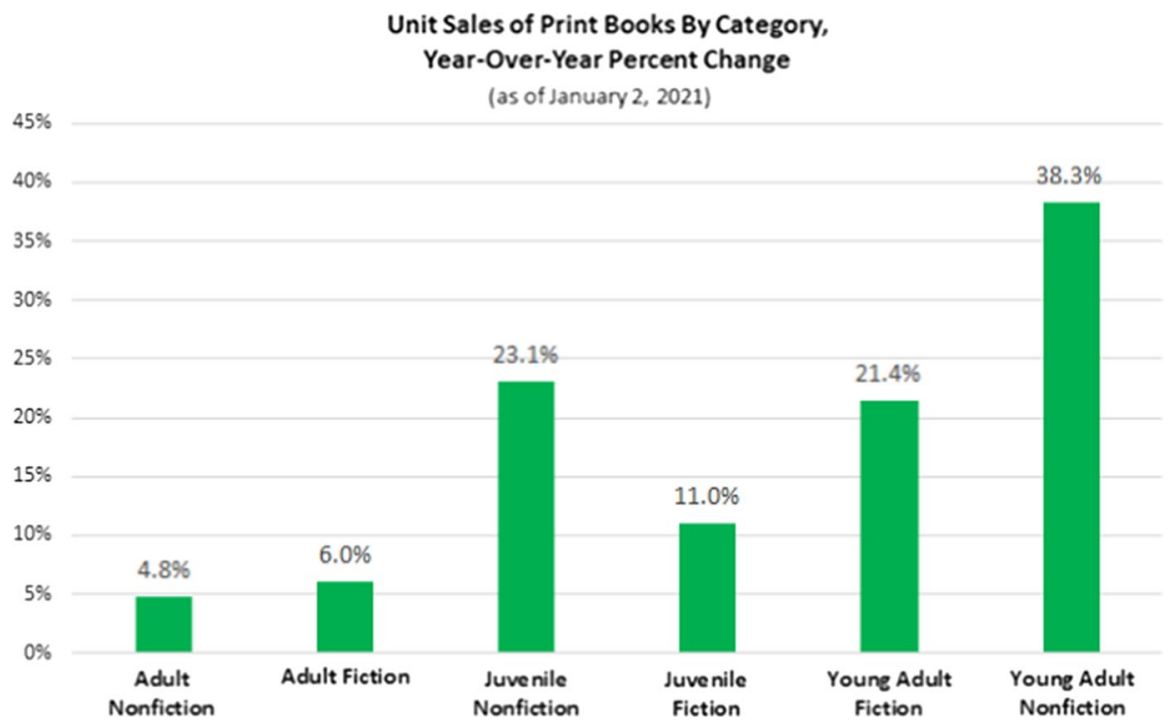

Fig. 2 Source: NPD BookScan and Publishers Weekly, December 2020

\section{Ebooks}

Energized by the early supply disruption in print books, the ebook format has been to some extent reborn during the pandemic, recovering from shrinking percentages of overall sales, and publisher disdain for the format.

The AAP pegged ebook revenues for October up $20.4 \%$ year-over-year. On a year-to-date basis, ebooks sales were up $16.5 \%$ [49]. 


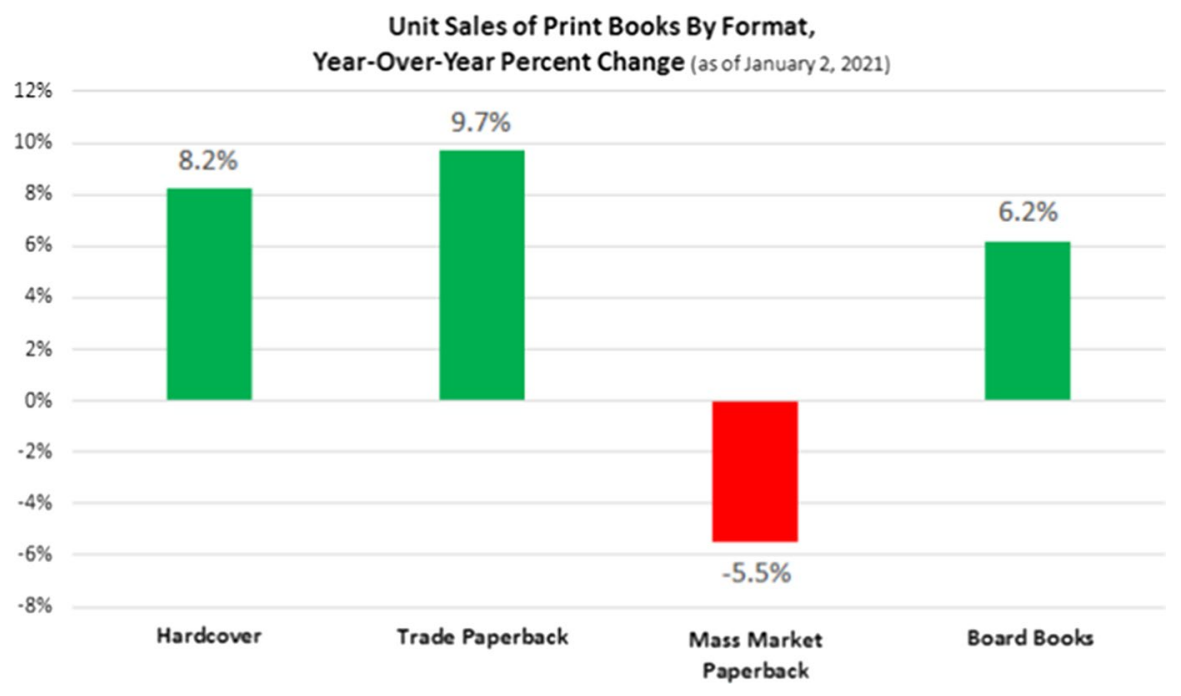

Fig. 3 Source: NPD BookScan and Publishers Weekly, December 2020

\section{Audiobooks}

After years of spectacular sales growth, audiobook sales growth slowed significantly in 2019: $16.4 \%$ versus $34.7 \%$ in 2018, based on data from the Audio Publishers Association (APA) [50]. NPD Group reported that unit digital audiobook sales were up 15\% through May, 2020 [51]. The AAP calculated that downloaded audio sales were up $17.3 \%$ to the end of October [48].

In the library market, Overdrive, which had been seeing year-over-year growth in audiobooks, saw depressed audiobook adoption in the pandemic. A possible reason cited by the company: commuters who had been listening to books in the car (or on mass transit) were no longer going into the office [52].

Overall, the numbers are positive for audio; only the pace of growth is slowing. Podcast consumption offers an interesting perspective on this data. Spotify reported in July that in its second quarter $21 \%$ of users were listening to podcasts, up from 19\% in Q1. Overall consumption of podcasts more than doubled [53]. Podtrac recorded $47 \%$ download growth for the 52-week period ending November 01, 2020 [54]. Are these listeners being lured away from audiobooks? Or are podcasts just part of an overall burgeoning audio trend?

\section{The Shift to Work from Home}

The pandemic has had an enormous impact on how publishing companies are staffed and how staff execute their work. And, by all accounts, that impact may mark a permanent shift in publishing workflows. No one expects publishing 
offices to disappear, but even the largest publishers are finding that they can keep the boat afloat with hardly a soul in their enormous, and enormously costly, Manhattan headquarters.

In early August, Penguin Random House confirmed that it will not return to its offices "until sometime (in 2021)... until it's safe and it's practical, whenever that may be."[55] Also in August, Hachette CEO Michael Pietsch sent out a note that "we will not be requiring anyone whose work can be done remotely to return to any of our offices for the foreseeable future.”[56]

\section{Academic Publishing Faces a Separate Set of Challenges}

Academic publishing sales are tough to pin down, in part because of reporting, and in part because of industry nomenclature. The only publicly-available data comes once again from the AAP. It monitors a category called "professional books," which includes business, medical, law, technical and scientific. Sales increased 3.3\% for the first ten months of 2020. It records a separate category for university presses, which garnered a modest $\$ 41$ million in sales in the same period, up 2.2\% from the same months in 2019 [48].

An analysis of university presses in the age of COVID-19 on the Ithaka $S+R$ $B l o g$ found that the transition to work from home had been largely seamless, amid a greater focus on process reengineering and concerns about funding in 2021. Citing predictions that the ongoing impact of the pandemic could lead to the permanent closure of 100 higher education institutions, several press directors wondered if the crisis might "strangle" some of the smaller university presses [57, 58].

\section{Conclusion}

The implications of COVID-19 on the book publishing sector are both subtle and deep. Most trade publishers enjoyed strong revenues in 2020, but with hugely lopsided sales by category, reflecting short-term social realities more than structural industry developments. Higher education publishers, in the midst of a long sectoral decline, enjoyed a good year, based on the emergency demand for digital educational content for students of all ages. Academic publishers, living in a world where budgets are adjusted by the year, not by the month, escaped 2020 mostly unscathed, yet with much cause for apprehension about their customers' budgets in the year ahead.

The changes in the retail landscape speak volumes. On the one hand, from now on publishers must treat bookselling as online- and digital-first, physical-second, with no further questions asked. Pre-COVID it was still valid for publishers to ponder "where does Amazon fit within our reseller channel strategy?" The question henceforth is "how do our reselling channels align with an online-first strategy (particularly for Amazon)?" And the mouse in the corner might be heard to squeak "and what should we do about the bookstores?" 
Although the sudden pandemic-driven shifts may slow or revert toward the mean with the achievement of a "new normal," we believe that important underlying changes will persist and continue to evolve.

\section{References}

1. Fitzgerald M. Fed raises its economic outlook slightly, Sees $4.2 \%$ growth next year and $5 \%$ unemployment rate. CNBC, 16 Dec 2020.

2. Employment situation summary. News release, BLS.gov. Jan 72021.

3. Ott M. During crucial holiday season, US consumer confidence slumps. Associated press, 21 Dec 2020.

4. DeCambre MUS. Stock market clinches superfecta of record highs Thursday as bulls pin buying to fiscal spending bill. MarketWatch, 17 Dec 2020.

5. Personal income and outlays, November 2020. BEA. 23 Dec 2020.

6. Consumer expenditures in 2015 report 1066 U.S Bureau of Labor Statistics, Apr 2017.

7. Pollak J. Why the U.S. economy will take off in 2021." Wall Street Journal, 10 Dec 2020.

8. Kennedy S. Wall Street sees world economy surging in 2021 from rocky start. Bloomberg, Dec 11, 2020.

9. Gillers H., Banerji G.U.S. States face biggest cash crisis since the great depression. Wall Street Journal, 28 Oct 2020.

10. U.S. Retail Sales, 1992-2020 Data. Tradingeconomics.com. Retrieved 14 Dec 2020.

11. Monthly Retail Trade, US Census Bureau. U.S. Census Bureau, 2020.

12. D'Innocenzio A. The holidays could make or break struggling stores. Associated Press. 21 Dec 2020.

13. Quarterly retail E-commerce sales 3rd quarter 2020. U.S. Census Bureau. 19 Nov 2020.

14. How is COVID-19 changing the retail consumer? Accenture. August 2020.

15. Unglesbee B. Retail is 'scrambling' to keep up with accelerated disruption in the COVID-19 era. Retail Dive. 25 Aug 2020.

16. Moldoveanu M. How our response to COVID-19 will remake higher Ed. Harvard business publishing, 2 Jul, 2010.

17. Govindarajan V, Srivastava A. A post-pandemic strategy for U.S. Higher Ed. Harvard business review, 2 Jun, 2020.

18. Nietzel M. Pandemic's impact on higher education grows larger; Now estimated to exceed \$120 Billion. Forbes, 29 Sep, 2020.

19. Chappatta, B. Back to school doubts crush textbook publishers. Bloomberg.com/Opinion, 20 Aug, 2020.

20. Holton K. Pearson's strategy pays off as COVID-19 accelerates online learning. Reuters, 14 Oct, 2020.

21. Press release. McGraw Hill, 28 Oct, 2020.

22. Investor presentation, Cengage, 12 Nov, 2020.

23. Bryant J. Chen, L-K. Dorn, M. School system priorities in the age of coronavirus. McKinsey.com, 21 Apr, 2020.

24. Arundel K. Three COVID-19 Education trends set to persist post-pandemic. EducationDive, 19 Oct, 2020.

25. Castelo M. The state of educational technology in a post-pandemic world. EdTech, 12 Nov, 2020.

26. COVID-19's impact on the education industry. EdWeek Market Brief, undated.

27. Pearson 9-month trading update (Unaudited). Pearson.com, 14 Oct, 2020.

28. Preliminary fiscal 2021 Q2 Update. McGraw Hill, 27 Oct, 2020.

29. Press release. Houghton Mifflin Harcourt announces third quarter 2020 results, intent to explore potential sale of HMH books \& media consumer publishing business. Houghton Mifflin Harcourt, 5 Nov, 2020.

30. Wallach O. The history of gaming in one chart. The World Economic Forum, 27 Nov, 2020.

31. Investing in the soaring popularity of gaming. Reuters, 18 Dec, 2018.

32. Friedlander JP. Mid-Year 2020 RIAA revenue statistics. RIAA, 2020.

33. Mulligan M. Spotify Q3 2020 earnings: The shift to free. MIDIA, 27 Nov, 2020. 
34. Carson J. ANTENNA streaming growth report, Q3 2020. ANTENNA, 30 Oct, 2020.

35. Churn rate drops to $38 \%$ among OTT services and $49 \%$ among vMVPDs. Parks Associates, 8 Dec, 2020.

36. Outlook for the US telecommunications, 2020 media, and entertainment industry media \& telecommunications Deloitte Center for Technology

37. Albanese A. A reset for library ebooks. Publishers Weekly. 9 Oct 2020.

38. Wilburn T. Libraries are dealing with new demand for books and services during the pandemic. NPR. 16 Jun 2020.

39. Schools' usage of ebooks and audiobooks surges in 2020 - OverDrive. Press release, OverDrive. 1 Dec 2020.

40. Final push for COVID relief: ALA issues broad call for library advocates. American Library Association. 8 Dec 2020.

41. Frederick JK. Wolff-Eisenberg C. Academic library strategy and budgeting during the COVID-19 pandemic. Ithaka S+R. 9 Dec 2020.

42. Evans B. What's Amazon's market share? ben-evans.com. 19 Dec 2019.

43. Monthly retail trade 2020 main page - US Census Bureau Census Gov

44. Shelf Awareness for Thursday, December 17, 2020. News, shelf awareness. 31 Dec 2020.

45. Amazon.com announces third quarter results. Press room, Amazon.com, 29 Oct 2020.

46. Trachtenberg J, Thomas P. Elliott Management to buy Barnes \& Noble in $\$ 475$ Million Deal. Wall Street Journal. 7 Jun 2019.

47. Kelly KJ. Book publishers worry that Barnes \& Noble hack will spur holiday snafus. New York Post. 24 Nov 2020.

48. AAP October 2020 StatShot report. Press release, AAP, 14 Dec 2020.

49. Milliot J. Print book sales rose 8.2\% in 2020. Publishers Weekly. 7 Jan 2021.

50. Friedman J. US book publishing remains resilient: print and ebook sales are growing. janefriedman. com. 30 Jul 2020.

51. Audiobooks: double-digit growth. Infographic, NPD Group. 2020.

52. DeCarbo, B. What-and How-People Were Reading During Covid-19., Wall Street Journal. 12 Dec 2020.

53. Steele A. Spotify's listening audience increases after pandemic slump. Wall Street Journal. 29 Jul 2020.

54. Podtrac Weekly Podcast Data Through November 1, 2020. Podtrac Blog. 2 Nov 2020.

55. Working from home is working for U.S. publishers. Beyond the Book, Copyright Clearance Center. 7 Aug 2020.

56. Cader M. HBG starts limited re-opening, but recommends remote work 'For the Foreseeable Future'. Publishers Lunch. 7 Aug 2020.

57. Brown L, University presses in the age of COVID-19, part 1. Ithaka S+R Blog. 24 Jun 2020.

58. Brown L. University presses in the age of COVID-19, Part 2. Ithaka S+R Blog. 30 Jun 2020.

Publisher's Note Springer Nature remains neutral with regard to jurisdictional claims in published maps and institutional affiliations. 